Article

\title{
Ingestion of Soil by Grazing Sport Horses
}

\author{
Stefan Jurjanz ${ }^{1, *}$, Claire Collas ${ }^{1}$, Carol Quish ${ }^{2}$, Bridget Younge ${ }^{2}$ and Cyril Feidt ${ }^{1}$ \\ 1 UR Animal et Fonctionnalités des Produits Animaux (URAFPA), Université de Lorraine-INRAE, \\ F-54000 Nancy, France; Claire.Collas@univ-lorraine.fr (C.C.); Cyril.Feidt@univ-lorraine.fr (C.F.) \\ 2 Department of Biological Sciences, Faculty of Science and Engineering, University of Limerick, \\ V94 T9PX Limerick, Ireland; carol.quish@ul.ie (C.Q.); bridget.younge@ul.ie (B.Y.) \\ * Correspondence: stefan.jurjanz@univ-lorraine.fr; Tel.: +33-372-74-41-61
}

Citation: Jurjanz, S.; Collas, C.; Quish, C.; Younge, B.; Feidt, C. Ingestion of Soil by Grazing Sport Horses. Animals 2021, 11, 2109. https://doi.org/10.3390/ani11072109

Academic Editors: Carol Hall and Anne Stevenson

Received: 21 June 2021

Accepted: 15 July 2021

Published: 15 July 2021

Publisher's Note: MDPI stays neutral with regard to jurisdictional claims in published maps and institutional affiliations.

Copyright: (c) 2021 by the authors. Licensee MDPI, Basel, Switzerland. This article is an open access article distributed under the terms and conditions of the Creative Commons Attribution (CC BY) license (https:// creativecommons.org/licenses/by/ $4.0 /)$.
Simple Summary: Soil ingestion has been well documented for the majority of outside reared animals but not in horses. As soil can be a vector of environmental pollutants, such studies generally aim at controlling exposure to pollutant uptake in food producing animals. In horses, ingestion of soil may cause gastrointestinal disorders such as sand colic or intestinal damage. Therefore, soil ingestion has been studied in Irish sport horses grazing at three levels of herbage offer: 2, 3 or 4\% of their body weight. Their soil intake was around $4 \%$ of the totally ingested dry matter corresponding to 543 to $648 \mathrm{~g}$ of dry soil per animal per day, which is quite similar to cattle in normal grazing conditions. Such amounts would clearly be an issue for food safety in areas with contaminated soil but also an animal welfare issue due to gastrointestinal damage. The height of the pastured grass sward seems to be a reliable criterion to indicate the level of risk of soil intake when horses graze short herbage in close proximity to the ground surface and should be moved to a new paddock.

Abstract: Data on soil ingestion in horses are lacking in contrast to other free-range animals. The importance of soil as a vector for environmental pollutants to food is less relevant in horses but several disorders secondary to soil ingestion, such as sand colic or enteritis have been reported. Therefore, soil ingestion has been studied on Irish sport horses grazing at three offered levels of daily herbage: 2,3 and $4 \%$ of their body weight. Soil ingestion was estimated by the faecal recovery of a soil natural marker. Horses had 4.5, 4.1 and 3.7\% of soil in their total intake respectively for the 2, 3 and $4 \%$ herbage offers. The $4 \%$ offer presented significantly less intake ( $543 \mathrm{~g} / \mathrm{d}$ ) compared to the more restricted offers (624 and $648 \mathrm{~g}$ respectively for 3 and $2 \%$ ). The post-grazing sward height was significantly lower on the $2 \%$ offer $(3.1 \mathrm{~cm})$ compared to the higher offers $(4.1$ and $4.4 \mathrm{~cm}$ respectively for 3 and $4 \%$ ). Thus, restricted herbage allowance made grazing closer to the ground and increased soil ingestion. The sward height appeared to be a reliable indicator to manage animal withdrawal from a pasture to limit soil ingestion and the risk of gastrointestinal pathologies caused by it.

Keywords: soil ingestion; equids; herbage offer; health; pasture; welfare

\section{Introduction}

In general, soil ingestion has no nutritional purpose except counterbalancing significant mineral deficits described as geophagia [1]. Nevertheless, it has some negative consequences. Firstly, global digestibility of the feed decreases as soil is very poor in organic matter, and its presence in the digestive tract disturbs the digestive flora. However, the main risk is that soil may be a vector of environmental pollutants, which can accumulate over a very long time in soil and is therefore one of the principal exposure pathways to food producing animals [2]. Hence, the evaluation of soil ingestion is a central point in risk assessment approaches. It has been studied in numerous food producing animals such as dairy cows [3,4], beef cattle [5,6], sheep [7,8], free-range pigs [9], free-range hens [10] and chicken [11]. Nevertheless, no such data are available in horses. In this species, the frame of food safety evaluation would not really match since consumption of horsemeat is-except 
in Central Asia (e.g., China, Kyrgyzstan, and Kazakhstan)—very low. Even if this reduced issue of food safety can explain the lower interest of the scientific community to study soil ingestion in horses, there are pathologic concerns justifying investigations. Indeed, superficial soil can carry an important amount of microorganisms in the stomach. Its relatively high $\mathrm{pH}$ would not very efficiently limit microbial growth. In addition, a deposit of ingested soil may sensitively reduce the relatively small volume of the horse's stomach. Moreover, Kilcoyne et al. [12] and also Niinstro et al. [13], both describe pathologic consequences such as sand colic or eroded intestinal mucosal lining without quantifying the responsible amount of ingested sand. Siwinska et al. [14] reported proportions of sand in stool but did not evaluate the corresponding level of ingestion. Thus, the ingestions of soil and sand by horses and its pathologic consequences has been clearly shown but no available data allows more accurate evaluation in horses.

Animals of comparable size, such as adult cattle, may ingest 30 to $100 \mathrm{~g}$ of dry soil per $100 \mathrm{~kg}$ of BW daily [3,6] under classical pasture conditions, and even up to $150 \mathrm{~g}$ per $100 \mathrm{~kg}$ of $\mathrm{BW}$ under poorer conditions [4,15], but the grass prehension differs notably between both species. Indeed, the height of the available grass is objectively measured with a herbometer and expressed as sward height (SH). It has been shown in ruminants that sward height (SH), especially post-grazing, is a good predictor of the level of soil ingestion $[4,6]$. Indeed, the shorter the grass sward, the closer to ground surface do animals graze and can consequentially ingest more soil along grass prehension. The anatomy of the equine mouth (i.e., movable lips and presence of maxillary) allows them to graze closer to the ground surface in comparison to cattle. This raises the following questions: Would the ingestion of soil by horses also increase when grass offered decreases, or would the difference of grass prehension between both species not (or less) expose horses to an increased risk of soil ingestion?

In the absence of any published data, the aim of this study was firstly to evaluate the ingestion of soil in realistic grazing conditions and secondly to investigate the link between the $\mathrm{SH}$ and level of soil ingestion in the equine species.

\section{Materials and Methods}

The study took place from 12 July to 2 September 2017 on a permanent grassland pasture located in Monaviddogue, Oola (Co Limerick Ireland). The experiment was conducted in farm like conditions and approved (Approval Number, 2017_6_1_ULAEC) by the University of Limerick Animal Ethics Committee (ULAEC).

\subsection{Animals and Experimental Design}

Six adult Irish Sport horses weighing $623 \pm 32 \mathrm{~kg}$ (mean \pm SEM) at the nutritional requirement level of maintenance and aged between 4 and 10 years were grouped by body weight $(\mathrm{BW})$ in pairs, which followed the treatments in the same order.

Three levels of Daily Herbage Allowance (DHA) were studied in these grazing horses during three successive periods via a Latin Square Design $3 \times 3$. DHA was expressed depending on the BW. The first level of DHA corresponded to the grass amount, which needs to be ingested in order to meet their daily requirements [16], i.e., $2 \%$ of the BW. Then grazing losses by trampling or selective ingestion behavior were taken into account defining two DHA levels 1.5 and 2 times higher at $3 \%$ and $4 \%$ of the BW.

Each period lasted 16 days and consisted of $10 \mathrm{~d}$ of adaption of the horses to the DHA on the new pasture plot followed by 6 days carrying out the intake measurements.

\subsection{Grazing Management and Vegetation Characteristics}

The study was carried out on a 2.6 ha plot of permanent pasture grassland covered with a predominant perennial ryegrass sward. The plot was divided into three paddocks. One paddock was used for each period and was mown beforehand at a different date to ensure identical vegetation stage for measurements. Each paddock was divided into three subpaddocks for each of the three pairs of horses receiving one of the three DHAs. The 
horses were managed with strip-grazing through the sub-paddock to control the DHA by adjusting the area offered relative to the herbage mass (HM) available on the day prior to grazing. The available HM on the next strip to be grazed was estimated every two days by measuring the pre-grazing sward height $(\mathrm{SH})$, and using a $\mathrm{SH}-\mathrm{HM}$ regression established on the experimental plot.

SH and HM were simultaneously measured once weekly in $0.09 \mathrm{~m}^{2}$ squares (30 by $30 \mathrm{~cm}$ ) randomly selected among areas of short, medium and tall swards on the next area to be grazed. SH inside each square was measured before and after herbage cut at $3.5 \mathrm{~cm}$ from the ground surface. For each square, herbage cut was weighed and then divided into two samples. One sample was dried for $24 \mathrm{~h}$ at $103{ }^{\circ} \mathrm{C}$ to determine the dry matter (DM) content of grass, then HM was calculated for the regression. The second samples from each square were pooled by sub-paddock to form a representative sample from each treatment at each measurement period. Representative pooled samples were dried during $48 \mathrm{~h}$ at $60^{\circ} \mathrm{C}$ and crushed over a $2 \mathrm{~mm}$ sieve before the acid insoluble ash (AIA) analyses necessary to assess soil ingestion.

The strips allocated to each DHA level were made using temporary electric fencing, and the two horses assigned during one period to a given treatment moved every second day with measurements of pre and post-grazing $\mathrm{SH}$ conducted using a rising plate herbometer. Back fencing prevented access by horses to the previously grazed strip. This management enabled us to offer the animals an identical sward and DHA during each 16-day-period. At each new time period, animals were weighed and the amount of grass to be offered was calculated to achieve the new DHA level based on the horses' BW.

\subsection{Dry Matter Intake}

The daily grass DM intake was estimated for each horse during the last $6 \mathrm{~d}$ of each period following the methodology described by Collas et al. [17] by dividing the faecal output (dry weight over $24 \mathrm{~h}$, attributable to grass) by the indigestible proportion of ingested grass (i.e., 1-DM digestibility of ingested grass). Therefore, the faeces of all animals were individually collected and weighed each day of measurement. Each dropping pile on the plot was attributed to one horse using small coloured plastic balls ( 1 colour per horse), which the animals received via a daily supply of $200 \mathrm{~g}$ of rolled barley (160 g DM), ingested without refusals. The total faecal output was weighed on a daily basis during the measurement period for each horse. A representative sample was collected daily from the center of the dropping piles in order to avoid soil or dust contamination, then dried for $72 \mathrm{~h}$ at $60^{\circ} \mathrm{C}$ to determine DM content, and afterwards crushed over a $2 \mathrm{~mm}$ sieve before AIA and crude protein $(\mathrm{CP})$ analyses.

The DM digestibility of ingested grass was estimated via the faecal CP content attributable to grass according to the equation of Mesochina et al. [18]. A correction was applied to take into account the amount of faecal CP attributable to barley [19] from CP content of barley and from the apparent CP digestibility of barley [16]. Finally, the total ingested DM corresponded to the sum of the previously estimated grass intake and $160 \mathrm{~g}$ DM of rolled barley.

\subsection{Ingestion of Soil}

Soil ingestion rate (SIR) was estimated by the method of Beyer et al. [20] and validated by Jurjanz et al. [21] using an internal marker: acid insoluble ash (AIA). Indeed, such marker compounds have been much more concentrated in the fraction, which should be traced (i.e., soil) in comparison to other ingested matrices (i.e., feed) as shown in previous studies $[4,9,11]$. Using its concentrations and an estimate of the DM digestibility of the total diet $(\mathrm{dDM})$, soil ingestion rate can be estimated as follows:

$$
\mathrm{SIR}[\%]=\left(\mathrm{AIA}_{\text {feed }}-\mathrm{AIA}_{\text {feces }}+\mathrm{dDM} \times \mathrm{AIA}_{\text {feces }}\right) /\left(\mathrm{dDM} \times \mathrm{AIA}_{\text {feces }}-\mathrm{AIA}_{\text {soil }}+\mathrm{AIA}_{\text {feed }}\right)
$$


Moreover, surface soil (layer $0-5 \mathrm{~cm}$ ) was sampled from each plot at each period. Then, AIA concentrations were analyzed in samples of soil, feed (grass and barley) and faeces as described previously [4]. The determination of the DM digestibility of the total diet $(\mathrm{dDM})$ was obtained from the following equation:

$$
\mathrm{dDM}=1-(\text { daily total fecal DM output/daily total DM intake) }
$$

Quantity of ingested soil (QIS) was calculated by multiplication of SIR and total ingested feed (grass and barley).

\subsection{Statistical Analyses}

Statistical analyses were performed using $R$ software, version 3.6.1 [22]. Intake variables (grass and total intakes, faecal output, DM digestibility), body weight and soil ingestion variables (fecal AIA content, SIR, QIS), were tested using Linear Mixed Models $(\mathrm{LMM})$ with treatment, period and treatment $\times$ period interaction as fixed effects, and individual as a random effect. A non-significant interaction between treatment and period was removed from final models. Each horse represented an experimental unit. Significant effects were declared at $p<0.05$ but tendencies (i.e., $p<0.10$ ) were also indicated. Multiple comparisons for each significant factor were realized using Tukey correction $(p<0.05)$ with glht function of multcomp package.

\section{Results}

\subsection{Grazing Parameters and Body Weight}

The pre-grazing sward height was $11.9 \mathrm{~cm}$ without any difference between the three treatments (Table 1). Contrarily, after grazing, the sward height at the lowest DHA was $3.1 \mathrm{~cm}$ and was significantly lower than the $4.4 \mathrm{~cm}$ at the highest DHA. The post-grazing $\mathrm{SH}$ at the intermediate DHA (i.e., $3 \%$ of the $\mathrm{BW}$ ) of $4.1 \mathrm{~cm}$ did not significantly differ from the other treatments (Table 1). Nevertheless, the post-grazing SH tended to be lower between the lowest and the two higher DHAs $(3.1 \mathrm{~cm}$ for $2 \%$ vs. $4.1 \mathrm{~cm}$ for $3 \%$ and $4.4 \mathrm{~cm}$ for $4 \%, p<0.10$ ).

Table 1. Ingestion of grass and soil depending on the Daily Herbage Allowance (DHA, \% of the body weight), period and $\mathrm{DHA} \times$ period interaction.

\begin{tabular}{|c|c|c|c|c|c|c|c|c|}
\hline \multirow[t]{2}{*}{ Variable } & \multicolumn{3}{|c|}{ DHA Level } & \multicolumn{2}{|c|}{ Residual Variation ${ }^{1}$} & \multicolumn{3}{|c|}{$p$-Value } \\
\hline & $2 \%$ & $3 \%$ & $4 \%$ & RSD & RSE & DHA & Period & DHA $\times$ Period \\
\hline \multicolumn{9}{|l|}{ Grazing } \\
\hline Pre-grazing sward height $(\mathrm{cm})$ & 12.0 & 12.2 & 11.5 & - & 0.9 & NS & - & - \\
\hline Post-grazing sward height $(\mathrm{cm})$ & $3.1 \mathrm{bB}$ & $4.1^{\mathrm{abA}}$ & $4.4^{\mathrm{aA}}$ & - & 0.7 & * & - & - \\
\hline Grass AIA ${ }^{2}$ content $\left(\mathrm{g} / \mathrm{kg} \mathrm{DM}^{3}\right)$ & 17.2 & 18.9 & 19.2 & - & 4.2 & NS & - & - \\
\hline Grass intake (kg DM/d) & 14.0 & 15.2 & 14.4 & 1.0 & - & NS & NS & NS \\
\hline Body weight $(\mathrm{kg})$ & $610^{b}$ & $630^{a}$ & $628^{a}$ & 7.3 & - & $* *$ & NS & NS \\
\hline \multicolumn{9}{|l|}{ Faeces } \\
\hline Faecal output (kg DM/d) & 7.5 & 8.0 & 7.7 & 0.2 & - & NS & NS & NS \\
\hline DM digestibility of ingested grass & 0.466 & 0.476 & 0.470 & 0.01 & - & NS & $*$ & NS \\
\hline DM digestibility of total diet & 0.470 & 0.480 & 0.473 & 0.01 & - & NS & * & NS \\
\hline Faecal AIA content (g/kg DM) & $60.3^{a}$ & $55.3^{\mathrm{ab}}$ & $51.1^{\mathrm{b}}$ & 4.5 & - & * & $* *$ & NS \\
\hline Soil AIA content ( $\mathrm{g} / \mathrm{kg}$ dry soil) & $697^{\mathrm{A}}$ & $678^{\mathrm{B}}$ & $697^{\mathrm{A}}$ & - & 13.9 & * & - & - \\
\hline Daily Soil Ingestion & & & & & & & & \\
\hline $\operatorname{SIR}^{4}(\%$ of total DM ingested $)$ & $4.5^{\mathrm{a}}$ & $4.1^{\mathrm{ab}}$ & $3.7^{\mathrm{b}}$ & 0.4 & - & * & $* *$ & NS \\
\hline Absolute QIS ${ }^{5}$ (g/horse) & $648^{a}$ & $624^{\mathrm{a}}$ & $543^{b}$ & 54.3 & - & * & $* * *$ & NS \\
\hline Relative QIS (g/100 kg BW) & $107^{\mathrm{a}}$ & $99 \mathrm{ab}$ & $89^{b}$ & 9.5 & - & * & $* * *$ & NS \\
\hline Relative QIS (g/kg metabolic BW) & $5.3^{\mathrm{aA}}$ & $5.0^{\mathrm{abA}}$ & $4.4^{\mathrm{bB}}$ & 0.5 & - & * & $* * *$ & NS \\
\hline
\end{tabular}

Significance of $p$-Values for tested effects was $<0.05$ for $^{*},<0.01$ for ${ }^{* *},<0.001$ for $^{* * *}$ and $>0.05$ for NS (non-significant); ${ }^{\text {a,b }}$ Values within a row with different superscripts (lowercase letters) differ significantly at $p<0.05$; ${ }^{\mathrm{A}, \mathrm{B}}$ Values within a row with different superscripts (capital letters) differ significantly at $p<0.1 ;{ }^{1}$ Mixed models on individual data gave a residual standard deviation (RSD) but simple models on plot data (two animals grazing together) resulted in residual standard error (RSE); ${ }^{2}$ AIA: acid insoluble ash; ${ }^{3}$ DM: dry matter; ${ }^{4}$ SIR: soil ingestion rate; ${ }^{5}$ QIS: quantity of ingested soil. 
The horses had a lower body weight on the smallest DHA in comparison to the two higher DHAs, 610 and $629 \mathrm{~kg}$, respectively $(p<0.05)$.

The AIA content of the allowed grass of $18 \mathrm{~g} / \mathrm{kg}$ DM on average did not significantly differ between treatments. In soil, there was a slightly lower content of AIA in the plots pastured for the intermediate treatment (678 vs. $697 \mathrm{~g} / \mathrm{kg}$ dry soil) but this very small difference did not reach the significance threshold $(p=0.07)$. Thus, the marker fraction AIA was 40 times more concentrated in soil than in the pastured grass (Table 1) allowing us to efficiently mark the soil.

\subsection{Grass Intake and Faecal Output}

The grass intake of the animals of $14.5 \mathrm{~kg} \mathrm{DM} / \mathrm{d}$ did not differ significantly between the treatments (Table 1 ) even if the raw mean between the lowest treatments differed by $1.2 \mathrm{~kg} / \mathrm{d}$ ( 14.0 and $15.2 \mathrm{~kg} / \mathrm{d}$ respectively for the DHAs of 2 and $3 \%, p>0.10$ ). The digestibility of the ingested grass did not differ between the three treatments with 0.47 on average (Table 1), but varied slightly between the second and the third period of the experiment $(0.46$ and 0.48 respectively, $p<0.05)$. In addition, the faecal output of $7.7 \mathrm{~kg}$ $\mathrm{DM} / \mathrm{d}$ on average did not differ between treatments (Table 1). The AIA content in the faeces decreased significantly from the lowest to the highest DHA (from 60.3 to $51.1 \mathrm{~g} / \mathrm{kg}$ DM respectively, $p<0.05$ ) with an intermediate concentration of $55.3 \mathrm{~g} / \mathrm{kg}$ DM (NS) for the DHA of $3 \%$ (Table 1). It is worth mentioning that horses during the first experimental period had significantly lower AIA contents in their faeces than during the periods 2 and 3 (respectively 47.9 and $59.4 \mathrm{~g} / \mathrm{kg} \mathrm{DM}, p<0.01$ ) but without any significant interaction with the treatment (Table 1).

\subsection{Ingestion of Soil}

The soil ingestion rate (SIR) increased significantly when the DHA decreased, from $3.7 \%$ at the highest DHA to $4.5 \%$ at the DHA of $2 \%(p<0.05$, Table 1$)$. The horses had an intermediate SIR of $4.1 \%$ at a DHA of 3\%, which did not significantly differ to the other treatments. In addition, the SIR was significantly $(p<0.05)$ lower during the first experimental period $(3.3 \%)$ compared to the other two periods $(4.5 \%)$ without any interaction to the treatment (Table 1).

The quantity of ingested soil (QIS) increased significantly $(p<0.05)$ from $543 \mathrm{~g} / \mathrm{d}$ at the highest DHA to $636 \mathrm{~g} / \mathrm{d}$ at the two more restrictive DHAs (Table 1). The slight numeric difference between the DHA treatments of 2 or $3 \%$ did not reach the significance threshold $(p>0.10)$. The relative soil ingestion per $100 \mathrm{~kg}$ of $\mathrm{BW}$ followed the same hierarchic order between the treatments (Table 1): highest for the lowest DHA at $107 \mathrm{~g} / 100 \mathrm{~kg}$ BW and was significantly $(p<0.05)$ higher than for the highest DHA at only $89 \mathrm{~g} / 100 \mathrm{~kg}$ BW. Horses had an intermediate relative QIS at the intermediate DHA at $99 \mathrm{~g} / 100 \mathrm{~kg} \mathrm{BW}$, which did not differ significantly from the two other treatments.

Absolute and relative QIS are significantly affected by the experimental period $(p<0.001)$ but every time without any interaction with the treatment (Table 1). In both cases, QIS in the first experimental period was significantly lower $(484 \mathrm{~g} / \mathrm{d}$ and $79 \mathrm{~g} / 100 \mathrm{~kg} \mathrm{BW}$ respectively for absolute and relative QIS) than during the periods 2 and $3(666 \mathrm{~g} / \mathrm{d}$ and $108 \mathrm{~g} / 100 \mathrm{~kg}$ BW respectively for the absolute and relative QIS).

\section{Discussion}

\subsection{The Very First Quantification of Soil Ingestion in Horses}

This very first quantification of soil ingestion by grazing equids showed proportions between 2.6 and $5.3 \%$ of the totally ingested DM, corresponding to 388 to $845 \mathrm{~g}$ per animal per day. Therefore, the ingestion of soil seems quite notable and should be integrated in risk evaluations for food safety and health. Indeed, such amounts could transport significant amounts of harmful compounds if the soil contained any cadmium or arsenic for example, but could also disturb the gastrointestinal milieu by its mechanical and microbiological adverse effects. 
Such levels of soil ingestion correspond to what has been reported in other herbivorous animals grazing on sufficient herbage allowances, for instance dairy cows $[3,4]$ or sheep $[7,23]$. Indeed, in such grazing conditions, these animals would hardly ingest more than $100 \mathrm{~g}$ of soil per $100 \mathrm{~kg}$ of BW corresponding to $10 \mathrm{~g}$ of soil per $\mathrm{kg}$ metabolic weight in line with our observations in grazing Irish sport horses. Nevertheless, the soil ingestion would significantly increase when pasture conditions deteriorate as winter grazing [8], in arid zones [15] or very high stocking rates [24]. In some extreme cases combining high stocking rates with very humid conditions, the proportion of soil in the ingested DM exceeds $20 \%$ during short periods [23-25]. Although these effects have been shown only in sheep and cattle, it seems likely that deteriorated grazing conditions would also increase the soil ingestion in horses, but the level of such increases needs to be studied.

\subsection{DHA and SH Are Good Indictors to Limit the Ingestion of Soil}

Pre-grazing SH (11.9 cm on average) did not differ significantly between treatments. As the post-grazing SH significantly decreased with DHA reduction $(4.4 \mathrm{~cm}$ for DHA $4 \%$ vs. $3.1 \mathrm{~cm}$ for DHA $2 \%$ ), indicating a restricted forage supply and by consequence inducing horses to graze shorter.

There were no significant differences in grass intake between treatments with an average of $14.6 \mathrm{~kg}$ DM per day (or $2.36 \% \mathrm{BW}$ ). Nevertheless, DHA were obtained by estimating the available herbage mass every 2 days by cutting the grass at $3.5 \mathrm{~cm}$ from the ground. Therefore, the grass of the $0-3.5 \mathrm{~cm}$ stratum was not taken into account in the estimates of DHA even though it is, at least partially, available to horses. On the one hand, horses are able to graze very close to the ground by means of the presence of both mandibular and maxillary incisors. On the other hand, the grass within the first few centimetres above the ground is more fibrous and has a higher DM content than grass in the leafy parts further from the ground. In dairy cows, Pérez-Prieto et al. [26] observed that the effect of pre-grazing grass mass on grass intake was affected by the height above which forage supply was estimated. According to the literature, both cattle and equines can graze down to $2-3 \mathrm{~cm}$, even less for equines $[17,26,27]$. This underestimation of the amount of forage offered has allowed the horses on DHA $2 \%$ to achieve a daily grass intake of $14.0 \mathrm{~kg}$ $\mathrm{DM}(2.33 \% \mathrm{BW})$ to cover their requirements by grazing shorter $(<3.5 \mathrm{~cm})$ than horses on DHA 3 and $4 \%(>4 \mathrm{~cm})$.

On the three treatments, the horses managed to ingest enough grass to cover their requirements. Although the horses grazed shorter on the DHA $2 \%$, this did not influence the DM digestibility of the ingested grass (on average 0.47 whatever the DHA). The postgrazing $\mathrm{SH}$ differences between the three treatments did not influence the quality or quantity of ingested grass. However, a significantly higher soil ingestion was observed on the DHA $2 \%$ than on the DHA $4 \%$, whether soil ingestion was expressed as a percentage of total DM intake, as a quantity per animal, or as a ratio of live or metabolic weight of the horses. On the DHA $2 \%$, grazing closer to the ground may have resulted in a higher soil ingestion either through direct contact with the soil surface or through the intake of grass closer to the ground and therefore potentially more soiled by soil particles adhered to the vegetation (dust, splash effect during a rainy episode, trampling, etc.).

In a study testing three DHA levels $(35,52.5$ and $70 \mathrm{~g} \mathrm{DM} / \mathrm{kg} \mathrm{BW} / \mathrm{d}$, estimated at ground level) with lactating saddle mares in a similar strip grazing system (new strip of fresh herbage offered every two days), Collas et al. [17] reported a linear effect of DHA on grass DM intake with an increase of $0.13 \mathrm{~kg}$ DM ingested $/ \mathrm{kg}$ DM of grass offered at ground level. These authors also observed a DHA influence on grazing behaviour with daily grazing time significantly longer on medium and high than on low DHA. Grazing activity on the second day on a strip was mainly influenced by DHA. Thus, it would be interesting to study grass and soil intakes of horses under more restrictive grazing conditions than those in the present study (e.g., DHA estimated at ground level). Such conditions could result in lower grass intake and higher soil ingestion (as a \% of total 
intake) than reported in the present study, at least for the lower DHA, with significant differences between treatments.

\subsection{Consequences on Health}

Ingestion of soil by horses has often been reported, especially with deleterious effects on horses' health justifying better integration of this aspect in the evaluation of animal welfare.

Firstly, different authors reported an uptake of consequent amounts of metals inducing toxic effects, which can hardly be explained only by the metal content in grazed vegetation. Indeed, Eamens et al. [28] reported zinc toxicity and hypocuprosis near industrial plants and others [29] also reported zinc poisoning with hypocuprosis in a mining district. Even though grass is often the main pathway of zinc ingestion, Madden [29] attributed an increase of zinc exposure to a stunted vegetation, implying a low herbage allowance and increased soil ingestion. Nevertheless, the most common symptoms related to soil ingestions by horses are attributable to sand accumulation and sedimentation in the intestine, with sand colic, diarrhea and enteritis developing [12-14]. In addition, several medical and surgical methods of sand removal have been tested and published [12,13]. A reduced frequency of enterolithiasis has been reported for Californian horses without daily access to pasture grazing [30]. The only quantification of sand in pathologic cases [14] found from $0.1 \mathrm{up}$ to $1.6 \mathrm{~g}$ of sand per $100 \mathrm{~g}$ of stool, which is clearly less than observed in our experiment. Although sandy soils seem to be linked to sand ingestion, soil ingestion can also occur on a wide range of soil textures [1], when geophagy was reported in 13 Australian horse farms, on soils with textures ranging from heavy clay to light sandy soil. It is noticeable that none of these studies quantified the soil ingestion. Another problem linked to soil ingestion can be associated with the telluric bacterium Rhodoccus equii, which can affect foals health [31]. Even if the aerial route of exposure is responsible for the most severe pathology, such as pneumopathy, most foals probably acquire a subclinical infection via the alimentary route [32]. Moreover, necrotizing enterocolitis can be observed. These three examples demonstrate that soil ingestion by horses can be an important parameter affecting their health.

\subsection{Perspectives}

This first study showed clearly that soil ingestion by grazing horses is not negligible at $500 \mathrm{~g}$ per day, which may affect animal welfare and health. More detailed work is necessary to precisely quantify the effects on soil ingestion such as different grazing managements, differences between horse categories (as for instance draft horses vs. sport ponies) or in horse farming specific conditions, such as raising in paddocks or in boxes with access during only some hours to a bare ground area. Such data would be very helpful to reduce the incidence of health problems related to ingested soil.

\section{Conclusions}

The first study to evaluate the ingestion of soil showed that grazing sport horses would ingest 3 to $4 \%$ of soil corresponding to approximately $600 \mathrm{~g}$ of dry soil per horse per day, which is quite similar to reported soil ingestion in adult cattle grazing in good conditions. These amounts are not negligible in the context where different pathologies due to ingested soil and sand are described and show the need to limit this involuntary intake in order to ensure the welfare of grazing horses. The amount of herbage offered and the sward height appear to be useful tools to limit soil ingestion as previously shown in other herbivorous animals.

Author Contributions: The experiment was conceptualized by all authors but carried out by the Irish authors C.Q. and B.Y. Data has been analyzed by C.C. and S.J. The original draft version has been written by C.C. and S.J. but all authors have read and agreed to the published version of the manuscript. B.Y. and C.F. supervised the project. The publication costs are shared between the Irish and the French. All authors have read and agreed to the published version of the manuscript. 
Funding: This research received no external funding.

Institutional Review Board Statement: The study was conducted according to the European Directive for the protection of animals used for scientific purposes (Directive 2010/63/UE) and approved (Approval Number, 2017_6_1_ULAEC) by the Ethics Committee of the University of Limerick (Republic of Ireland).

Data Availability Statement: All data is available from the authors and can be accessed after a simple request containing a reasonable motivation.

Acknowledgments: The authors thank warmly Pamela Hartmeyer from the URAFPA team (Nancy, France) for technical support and Thomas Schulze from A + T Scientific Translation Service (Chelmsford, UK) for English proofreading.

Conflicts of Interest: The authors declare no conflict of interest.

\section{References}

1. McGreevy, P.D.; Hawson, L.; Haberman, T.C.; Cattle, S.R. Geophagia in horses. A short note on 13 cases. Appl. Anim. Behav. Sci. 2001, 71, 119-125. [CrossRef]

2. Rychen, G.; Jurjanz, S.; Toussaint, H.; Feidt, C. Dairy ruminant exposure to persistent organic pollutants and excretion to milk. Animal 2008, 2, 312-323. [CrossRef] [PubMed]

3. Fries, G.F.; Marrow, G.S.; Snow, P.A. Soil Ingestion by Dairy Cattle. J. Dairy Sci. 1982, 65, 611-618. [CrossRef]

4. Jurjanz, S.; Feidt, C.; Pérez-Prieto, L.A.; Ribeiro Filho, H.M.N.; Rychen, G.; Delagarde, R. Soil intake of lactating dairy cows in intensive strip-grazing systems. Animal 2012, 6, 1350-1359. [CrossRef] [PubMed]

5. Jurjanz, S.; Collas, C.; Lastel, M.L.; Godard, X.; Archimède, H.; Rychen, G.; Mahieu, M.; Feidt, C. Evaluation of soil intake by growing creole steers in common grazing systems in the French West Indies. Animal 2017, 11, 1363-1371. [CrossRef]

6. Collas, C.; Mahieu, M.; Tricheur, A.; Crini, N.; Badot, P.M.; Archimède, H.; Rychen, G.; Feidt, C.; Jurjanz, S. Cattle exposure to environmental contaminants through soil intake. The case-study of tropical grazing practices in French West Indies. Sci. Total Environ. 2019, 668, 161-170. [CrossRef] [PubMed]

7. Field, A.C.; Purves, D. The intake of soil by the grazing sheep. Proc. Nutr. Soc. 1964, 23, XXIV-XXV.

8. Abrahams, P.W.; Steigmajer, J. Soil Ingestion by sheep grazing the metal enriched foodplain soils of Mid-Wales. Environ. Geochem. Health 2003, 25, 17-24. [CrossRef]

9. Jurjanz, S.; Roinsard, A. Valorisation de l'herbe par des truies en plein air. AlterAgri 2014, 108, 25-26.

10. Jondreville, C.; Travel, A.; Besnard, J.; Feidt, C. Intake of herbage and soil by free-range laying hens offered a complete diet compared to a whole-wheat diet. In Proceedings of the XIIIth European Poultry Conference, Tours, France, 23-27 August 2010.

11. Jurjanz, S.; Germain, K.; Juin, H.; Jondreville, C. Intake of plants and soil of free ranged chicken reared outside in plots under trees or covered with grass. Animal 2015, 9, 888-898. [CrossRef] [PubMed]

12. Kilcoyne, I.; Dechant, J.E.; Spier, S.J.; Spriet, M.; Nieto, J.E. Clinical findings and management of 153 horses with large colon sand accumumations. Vet. Surg. 2017, 46, 860-867. [CrossRef]

13. Niinistö, K.E.; Ruohoniemi, M.O.; Freccero, F.; Raekallio, M.R. Investigation of the treatment of sand accumulations in the equine large colon with psyllium and magnesium sulphate. Vet. J. 2018, 238, 22-26. [CrossRef]

14. Siwinska, N.; Luczka, A.; Slowikowska, M.; Niedzwiedz, A. Assessment of sand accumulation in the gastrointestinal tract and its excretion with stool in Silesian foals. Pol. J. Vet. Sci. 2019, 22, 337-343.

15. Kirby, D.R.; Stuth, J.W. Soil-Ingestion Rates of steers Following Brush Management in Central Texas. J. Range Managem. 1980, 33, 207-209. [CrossRef]

16. Equine Nutrition. INRA Nutrient Requirements, Recommended Allowances and Feed Tables; Martin-Rosset, W., Ed.; Wageningen Academic Publishers: Wageningen, The Netherlands, 2015; 696p. [CrossRef]

17. Collas, C.; Dumont, B.; Delagarde, R.; Martin-Rosset, W.; Fleurance, G. Energy supplementation and herbage allowance effects on daily intake in lactating mares. J. Anim. Sci. 2015, 93, 2520-2529. [CrossRef] [PubMed]

18. Mesochina, P.; Martin-Rosset, W.; Peyraud, J.L.; Duncan, P.; Micol, D.; Bouot, S. Prediction of the digestibility of the diet of horses: Evaluation of faecal indices. Grass Forage Sci. 1998, 93, 189-196. [CrossRef]

19. Delagarde, R.; Peyraud, J.-L.; Delaby, L. Influence of carbohydrate or protein supplementation on intake, behaviour and digestion in dairy cows strip-grazing low-nitrogen fertilized perennial ryegrass. Ann. Zootech. 1999, 48, 81-96. [CrossRef]

20. Beyer, N.W.; Connor, E.E.; Gerould, S. Estimates of Soil Ingestion by Wildlife. J. Wildl. Managem. 1994, 58, 375-382. [CrossRef]

21. Jurjanz, S.; Germain, K.; Dziurla, M.A.; Juin, H.; Jondreville, C. Use of acid-insoluble ash and n-alkanes as markers of soil and plant ingestion by chickens. Anim. Feed Sci. Technol. 2014, 172, 92-101. [CrossRef]

22. R Development Core Team. R: A Language and Environment for Statistical Computing; R Foundation for Statistical Computing: Vienna, Austria, 2019.

23. Smith, K.M.; Abrahams, P.W.; Dagleish, M.P.; Steigmajer, J. The intake of lead and associated metals by sheep grazing miningcontaminated floodplain pastures in mid-Wales, UK: I. Soil ingestion, soil-metal partitioning and potential availability to pasture herbage and livestock. Sci. Total Environ. 2009, 407, 3731-3739. [CrossRef] 
24. Healy, W.B. Ingestion of soil by dairy cows. N. Z. J. Agric. Res. 1968, 11, 487-499. [CrossRef]

25. McGrath, D.; Poole, D.B.R.; Fleming, G.A.; Sinnott, J. Soil ingestion by grazing sheep. Ir. J. Agric. Res. 1982, 21, 135-145.

26. Pérez-Prieto, L.A.; Peyraud, J.-L.; Delagarde, R. Pasture intake, milk production and grazing behaviour of dairy cows grazing low-mass pastures at three daily allowances in winter. Livest. Sci. 2011, 137, 151-160. [CrossRef]

27. Pérez-Prieto, L.A.; Peyraud, J.-L.; Delagarde, R. Does pre-grazing herbage mass really affect herbage intake and milk production of strip-grazing dairy cows? Grass Forage Sci. 2012, 68, 93-109. [CrossRef]

28. Eamens, G.J.; Macadam, J.F.; Laing, E.A. Skeletal abnormalities in young horses associated with zinc toxicity and hypocuprosis. Aust. Vet. J. 1984, 61, 205-207. [CrossRef]

29. Madden, V.; Drake, D. Zinc Toxicosis in Horses. Memorandum US EPA 2005, KBD9807418102, 3. Available online: https: / / semspub.epa.gov/work/07/40249734.pdf (accessed on 31 May 2021).

30. Hassel, D.M.; Aldridge, B.M.; Drake, C.M.; Snyder, J.R. Evaluation of dietary and management risk factors for enterolithiasis among horses in California. Res. Vet. Sci. 2008, 85, 476-480. [CrossRef]

31. Takai, S.; Zhuang, D.; Huo, X.W.; Madarame, H.; Gao, M.H.; Tan, Z.T.; Gao, S.C.; Yan, L.J.; Guo, C.M.; Zhou, X.F.; et al. Rhodococcus equi in the soil environment of horses in Inner Mongolia, China. J. Vet. Med. Sci. 2006, 68, 739-742. [CrossRef] [PubMed]

32. Yager, J.A.; Duder, C.K.; Prescott, J.F.; Zink, M.C. The interaction of Rhodococcus equi and foal neutrophils in vitro. Vet. Microbiol. 1987, 14, 287-294. [CrossRef] 